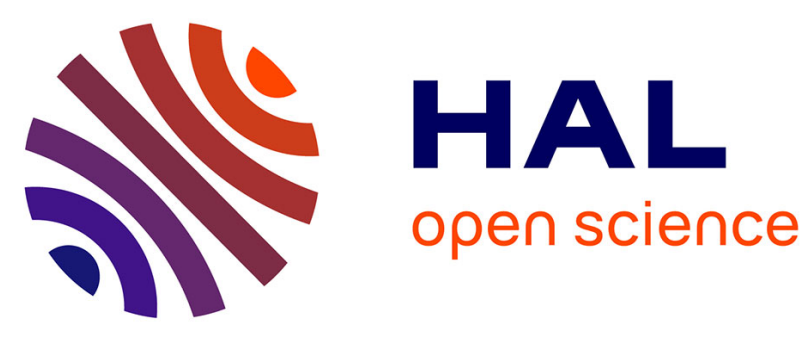

\title{
Screening and Biosecurity for White-Nose Fungus Pseudogymnoascus destructans (Ascomycota: Pseudeurotiaceae) in Hawai'i1
}

Violeta Zhelyazkova, Nia Toshkova, Serena E. Dool, Frank Bonaccorso, Corinna Pinzari, Kristina Montoya-Aiona, Sebastien J. Puechmaille

\section{To cite this version:}

Violeta Zhelyazkova, Nia Toshkova, Serena E. Dool, Frank Bonaccorso, Corinna Pinzari, et al.. Screening and Biosecurity for White-Nose Fungus Pseudogymnoascus destructans (Ascomycota: Pseudeurotiaceae) in Hawai'i1. Pacific Science, 2019, 73 (3), pp.357-365. 10.2984/73.3.4 · hal-03136269

\section{HAL Id: hal-03136269 \\ https://hal.umontpellier.fr/hal-03136269}

Submitted on 9 Feb 2021

HAL is a multi-disciplinary open access archive for the deposit and dissemination of scientific research documents, whether they are published or not. The documents may come from teaching and research institutions in France or abroad, or from public or private research centers.
L'archive ouverte pluridisciplinaire HAL, est destinée au dépôt et à la diffusion de documents scientifiques de niveau recherche, publiés ou non, émanant des établissements d'enseignement et de recherche français ou étrangers, des laboratoires publics ou privés. 


\title{
BioOne COMPLETE
}

\section{Screening and Biosecurity for White-Nose Fungus Pseudogymnoascus destructans (Ascomycota: Pseudeurotiaceae) in Hawai'i1}

\author{
Authors: Zhelyazkova, Violeta L., Toshkova, Nia L., Dool, Serena E., \\ Bonaccorso, Frank J., Pinzari, Corinna A., et al.
}

Source: Pacific Science, 73(3) : 357-365

Published By: University of Hawai'i Press

URL: https://doi.org/10.2984/73.3.4

BioOne Complete (complete.BioOne.org) is a full-text database of 200 subscribed and open-access titles in the biological, ecological, and environmental sciences published by nonprofit societies, associations, museums, institutions, and presses.

Your use of this PDF, the BioOne Complete website, and all posted and associated content indicates your acceptance of BioOne's Terms of Use, available at www.bioone.org/terms-of-use.

Usage of BioOne Complete content is strictly limited to personal, educational, and non - commercial use. Commercial inquiries or rights and permissions requests should be directed to the individual publisher as copyright holder.

BioOne sees sustainable scholarly publishing as an inherently collaborative enterprise connecting authors, nonprofit publishers, academic institutions, research libraries, and research funders in the common goal of maximizing access to critical research. 


\title{
Screening and Biosecurity for White-nose Fungus Pseudogymnoascus destructans (Ascomycota: Pseudeurotiaceae) in Hawai ${ }^{\prime}{ }^{1}$
}

\author{
Violeta L. Zhelyazkova, ${ }^{2,3}$ Nia L. Toshkova, ${ }^{2,3}$ Serena E. Dool, ${ }^{2}$ \\ Frank 7. Bonaccorso, ${ }^{4}$ Corinna A. Pinzari, ${ }^{5}$ Kristina Montoya-Aiona,${ }^{4}$ and \\ Sebastien 7. Puechmaille ${ }^{2,6,7}$
}

\begin{abstract}
Introduced pathogens causing emerging infectious diseases (EIDs) are serious contemporary threats to animal, plant, and ecosystem health. The invasive fungus, Pseudogymnoascus destructans, has established populations of European origin in North America, resulting in mass mortality of several hibernating bat species. Extensive monitoring for this pathogen exists in Europe and North America, but limited screening is taking place elsewhere. We report results from cave surveys on Hawai' $i$ Island. Substrates in 10 lava-tube caves with elevations up to $3,045 \mathrm{~m}$ were swabbed providing samples for screening $P$. destructans. Interior cave air temperatures spanned temperatures suitable for the growth and survival of $P$. destructans. Using quantitative PCR, all 85 samples tested were negative for the presence of $P$. destructans. The biology of the Hawaiian hoary bat (Lasiurus cinereus semotus) in relation to its unusual use of high elevation caves is discussed because these bats could come into contact with $P$. destructans should it arrive in Hawai' $i$. Large numbers of cave enthusiasts visit Hawaiian caves from across the world after having been inside caves elsewhere including areas with $P$. destructans. Thus, resource managers in Hawai' $i$ and other remote areas may want to consider the potential for $P$. destructans to arrive unintentionally via human activities. Biosecurity measures and periodic screening for $P$. destructans are especially important in Hawai'i given the presence of high elevation caves with suitable temperatures for its growth. If $P$. destructans was introduced to Hawaiian caves, it could affect the local fauna but also act as a source population for colonisations elsewhere.
\end{abstract}

Keywords: white-nose syndrome, bat conservation, emerging infectious diseases, cave management, pathogen pollution

ONE OF THE CONSEQUENCES OF human activities on Earth is the invasion of new species into previously unoccupied areas, which is considered the second most important cause

\footnotetext{
${ }^{1}$ Logistical and financial support for our research were provided by the U.S. Geological Survey, Pacific Island Ecosystems Research Center, the Student Council of Sofia University "St. Kliment Ohridski", and the ELTA 90 Company. Manuscript accepted 19 February 2019.

${ }^{2}$ Zoological Institute and Museum, University of Greifswald, 26 Loitzer Str., 17489 Greifswald, Germany.

Pacific Science (2019), vol. 73, no. 3:357-365

doi: $10.2984 / 73.3 .4$

(C) 2019 by University of Hawai'i Press.

All rights reserved.
}

of biodiversity loss after habitat destruction (Vitousek et al. 1997). The introduction of non-native pathogens falls into this category. These pathogens can cause emerging

\footnotetext{
${ }^{3}$ National Museum of Natural History, Bulgarian Academy of Sciences, 1 Tsar Osvoboditel Str., 1000 Sofia, Bulgaria.

${ }^{4}$ U.S. Geological Survey, Pacific Island Ecosystems Research Center, P.O. Box 44, Hawai'i National Park, HI 96718, USA.

${ }^{5}$ Hawai'i Cooperative Studies Unit, University of Hawai'i at Hilo, Hilo, HI 96720, USA.

${ }^{6}$ ISEM, University of Montpellier, CNRS, EPHE, IRD, Montpellier, France.

${ }^{7}$ Corresponding author

(e-mail: sebastien.puechmaille@umontpellier.fr).
} 
infectious diseases (EIDs) which are among the most serious contemporary threats to wildlife and have the potential to cause mass mortalities and local extinctions (e.g. Daszak et al. 2000, De Castro and Bolker 2005). Global movements of humans certainly have facilitated this process over the past 40,000 years (Roques et al. 2016, Bertelsmeier et al. 2017, Dyer et al. 2017, Smith et al. 2017). The rates at which EIDs have spread, as well as their severity and geographical range, have increased significantly in recent decades, a phenomenon known as "pathogen pollution" (Cunningham et al. 2003). This trend is especially valid for fungal infections, which have caused $65 \%$ of the documented diseasedriven species extinctions between 1995 and 2010 (Fisher et al. 2012). For example, the most harmful alien pathogens recorded recently in Hawai' $i$ are fungal blights belonging to the Ceratocystis genus that are currently threatening entire forests of Hawai'i's most ecologically important tree species, 'ōhi'a (Metrosideros polymorpha). Known as Rapid 'Ōhi'a Death (ROD), the corresponding disease can kill a tree within weeks, by settling in the sapwood and blocking the water supply from the roots. The impacts of forest loss could be enormous, with the potential to damage entire native ecosystems, to affect native bird and insect species which are dependent on 'ohi'a as a food source and a habitat, and even to disrupt watershed processes that deliver fresh water (Stone 2017). Recent research by Barnes et al. (2018) revealed two species, C. lucoobia and $C$. buliobia, specific to $M$. polymorpha but belonging to different phylogenetic lineages, as causative agents of ROD. Microsatellite analysis demonstrated that both are clonal which implies recent introductions but the exact origin of the pathogens remains unknown.

The role of emerging mycoses in the Animal Kingdom is also increasingly recognised, mainly due to several unprecedented zoonoses, such as chytridiomycosis in amphibians and White-Nose Syndrome (WNS) in hibernating bats (Fisher et al. 2016). The fungal pathogen Pseudogymnoascus destructans, causative agent of WNS, was introduced to North America from Eurasia and led to one of the greatest recorded die-offs of mammals in modern history (Puechmaille et al. 2011a, Frick et al. 2015, Leopardi et al. 2015, Drees et al. 2017). Typical symptoms of WNS are white fungal growth on the muzzle, ears, and wings, abnormal winter activity (Reeder and Turner 2008, Veilleux 2008, Turner and Reeder 2009), disrupted water balance, and premature depletion of fat reserves (Cryan et al. 2010). Pseudogymnoascus destructans possesses all the key biological features that make fungal pathogens so deadly. These are: (1) high virulence - P. destructans led to 30 to $99 \%$ decreases in affected bat populations in the first few years after its emergence (Puechmaille et al. 2011a, Frick et al. 2016); (2) long-lived environmental stages $P$. destructans can feed saprotrophically and successfully survive in cave substrates even without bats being present, making caves an environmental reservoir (Puechmaille et al. 2011b, Raudabaugh and Miller 2013, Reynolds et al. 2015); (3) large numbers of host species, including those that are tolerant to the pathogen (USFWS 2017) and can spread the pathogen further, introducing it to new susceptible host populations (Petit and Puechmaille 2015).

Pseudogymnoascus destructans is native to Europe and Asia, where it is widely distributed but not associated with mass morbidity or mortality (Puechmaille et al. 2010, Puechmaille et al. 2011b, Zukal et al. 2016, Fritze and Puechmaille 2018, Kovacova et al. 2018). The fungus was introduced, most probably by humans, from Europe to North America (Leopardi et al. 2015, Drees et al. 2017). This emphasizes the need for broader awareness and stricter control regarding the transport of biological material including un-intentional transport (Fisher et al. 2012). Following the initial introduction in New York State, the fungus has expanded to 7 Canadian provinces and 33 US states as of summer 2018. The southernmost point where it has been detected is in the State of Texas $\left(31.96^{\circ} \mathrm{N}, 99.90^{\circ} \mathrm{W}\right)$, and the westernmost point is in the State of Washington $\left(47.49^{\circ} \mathrm{N}, 121.78^{\circ} \mathrm{W}\right.$ ) (USFWS 2018). Although the exact mechanisms of $P$. destructans spread have not been studied in detail, it seems clear that bats are largely contributing to the spread but long-distance 
dispersal (such as the case in Washington State) are suspected to be human-mediated (Petit and Puechmaille 2015, Lorch et al. 2016). As communicable wildlife diseases are practically impossible to stop once they emerge (Fisher et al. 2012), it is of utmost importance to know the distribution of the causative pathogen. Indeed, this information is needed to set up measures and monitoring programs to prevent the introduction from regions with pathogen presence (either native or introduced) to new regions. Given that many invasions could have originated from a successful invasive population rather than from the native range (the Bridgehead Effect: Lombaert et al. 2010), it becomes important to monitor regions in close contact with recently invaded territories.

An example of such a place is the Hawaiian Archipelago, which is tightly linked to North America, Asia, Europe, and Australia in terms of tourism and trade. Although no reports of $P$. destructans or WNS have come from tropical zones, the high altitude lava tubes on Hawai' $i$ and Maui Islands offer low temperatures that are optimal for $P$. destructans growth (Verant et al. 2012).

The Hawaiian hoary bat (Lasiurus cinereus semotus), known to Hawaiians as 'Ōpe'ape'a, is the only bat species in Hawai'i. It usually roosts in foliage (Bonaccorso et al. 2015) but shows significant activity associated with foraging at high altitude lava tube cave entrances and internal passages, particularly during winter months (Bonaccorso et al. 2016). Numerous bat carcasses have been found in cave interiors (up to 200 in one cave: Bonaccorso et al. 2016) of Mauna Loa Volcano which has a summit of 4,169 m. Hawaiian hoary bats often enter caves located above the cloud inversion layer presumably to feed on the large populations of Peridroma moth species when heavy rains do not favour foraging at lower altitudes (Bonaccorso et al. 2016). Despite extensive searching by Bonaccorso et al. (2016), there is currently no evidence to suggest that $L$. cinereus semotus is using lava tubes as hibernacula; thus, the potential risk for the Hawaiian hoary bat being impacted by WNS is currently considered low. However, while this bat only enters shallow torpor when day-roosting in its summer lowland range with body temperatures approaching $25^{\circ} \mathrm{C}$ (Montoya-Aiona and Moura, personal observations), the winter biology and the possibility of it entering deep torpor for prolonged periods is unknown. Also, as the fungus can persist and grow in sediments without the presence of bats (Reynolds et al. 2015), if $P$. destructans was introduced to Hawaiian caves, Hawai'i could act as a bridgehead population for further colonisations elsewhere in the world. Thus, monitoring to detect the potential arrival of $P$. destructans in Hawai' $i$ is a prudent and pro-active action.

\section{MATERIALS AND METHODS}

During July and August 2015, 10 volcanic caves were visited on the Island of Hawai' $i$ in order to test for the presence of $P$. destructans (Figure 1). Most of these caves were chosen based on their high elevation, which provides relatively cool temperatures suitable for the

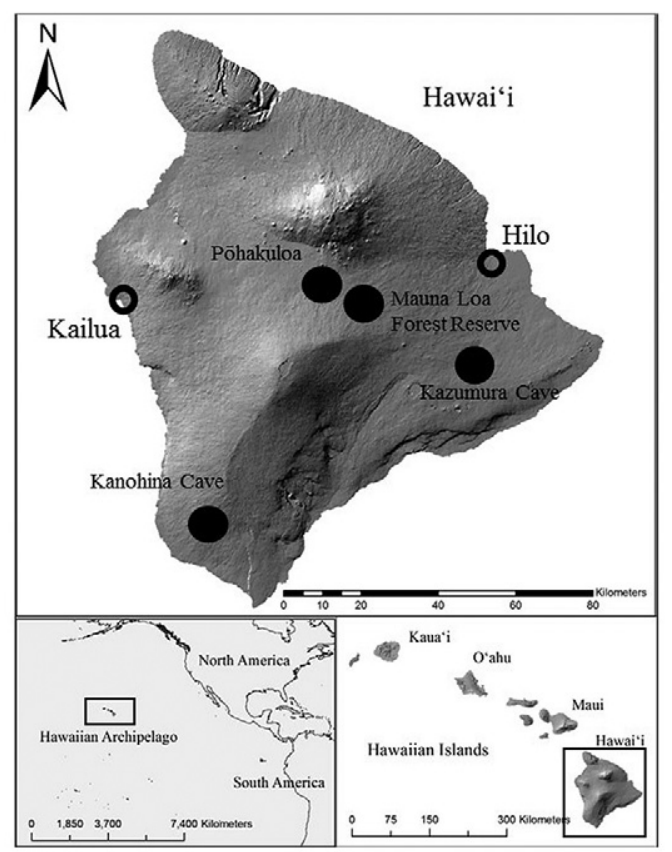

Figure 1. Map of Hawaii Island, with major cities Hilo and Kailua (black circles), and regional locations of sampled lava tubes (solid black circles). Bottom left map depicts the Hawaiian Archipelago in relationship to North American continent. Bottom right map shows Hawai'i Island in relation to other Hawaiian Islands. 
TABLE 1

Description of Sample Collection Sites

\begin{tabular}{ccclcll}
\hline \hline $\begin{array}{c}\text { Lava } \\
\text { Tube }\end{array}$ & $\begin{array}{c}\text { Samples } \\
\text { Collected }\end{array}$ & $\begin{array}{c}\text { Elevation } \\
(\mathrm{m})\end{array}$ & \multicolumn{1}{c}{ Region } & $\begin{array}{c}\text { Temperature } \\
\left({ }^{\circ} \mathrm{C}\right)\end{array}$ & $\begin{array}{c}\text { Human } \\
\text { Activities }\end{array}$ & $\begin{array}{c}\text { \% Nights with Bat } \\
\text { Calls/Month } \pm \text { SD }\end{array}$ \\
\hline 1 & 5 & 240 & Ocean View, Kanohina system & 21.6 & Mass tourism & ns \\
2 & 10 & 1,000 & Kazumura system & 20.7 & Mass tourism & ns \\
3 & 10 & 1,130 & Kazumura system & 15.8 & Open to caving & $\mathrm{ns}$ \\
4 & 5 & 1,450 & Ocean View, Kanohina system & 16.5 & Restricted entry ns \\
5 & 5 & 2,188 & Pōhakuloa Military Training Area & 12.4 & Restricted entry ns \\
6 & 10 & 2,341 & Mauna Loa Forest Reserve & 10.7 & Restricted entry* $42 \pm 0.40$ \\
7 & 10 & 2,341 & Mauna Loa Forest Reserve & 11.6 & Restricted entry* $59 \pm 0.42$ \\
8 & 10 & 2,533 & Mauna Loa Forest Reserve & 9.2 & Restricted entry* $54 \pm 0.22$ \\
9 & 10 & 2,725 & Mauna Loa Forest Reserve & 9.0 & Restricted entry* $59 \pm 0.36$ \\
10 & 10 & 3,045 & Mauna Loa Forest Reserve & 7.0 & Restricted entry* $38 \pm 0.13$ \\
\hline
\end{tabular}

Listed temperatures are the lowest measured during our visits during daylight hours. *A permit for cave entry is required from Hawaii Department of Land and Natural Resources. Lava tubes 1 through 5 were not sampled ("ns") for bat activity outside entrances. Lava tubes 6 through 10, winter season bat activity as percent nights with bat calls per month, taken from Bonaccorso et al. 2016.

survival and growth of $P$. destructans. Six of the ten lava tubes, in the Mauna Loa Forest Reserve, demonstrated bat presence during the winter season, through acoustic surveys at the surface (Bonaccorso et al. 2016). Temperature was measured at the deepest part reached in each cave, which was always in the dark zone. Considering that caves are approximately thermally isolated systems (Badino 2004) and that cave temperatures at more than a few hundred meters from the entrance rarely vary by more than $2{ }^{\circ} \mathrm{C}$ daily or seasonally, one data point per sampling site can be considered a good approximation of mean annual temperature at that site. In the case of smaller caves, variations will be higher but as we conducted our fieldwork in the summer and during the daytime, actual mean temperatures would be lower and not higher than the one we measured. Temperatures in the Kanohina and Kazumura cave systems are at the limit of the growth range of $P$. destructans, but these sites were included because of the large number of tourists and cave enthusiasts (in the range of thousands) that visit them annually. Access for sampling in the Mauna Loa Forest Reserve was granted through a research permit from the Hawai'i Department of Land and Natural Resources. Access to private sites was granted by the owners.
Samples were collected from cave walls, 1$2 \mathrm{~m}$ from the floor at various distances from the entrance, and different sub-habitats (e.g. wet/dry, muddy/not muddy, lava rock/calcite crystals) were equally represented (Table 1). We chose to sample walls (and not the floor) as they are the surfaces bats would most likely come in contact with if they happen to enter the cave. Moreover, in contrast to karst caves, there is no significant amount of sediment found on lava tube floors. Sterile cotton swabs were used, and an area of $5-10 \mathrm{~cm}^{2}$ was covered by gently rolling the swab across the surface 4 times. Individual swabs were placed in sterile $2 \mathrm{ml}$ Eppendorf tubes filled with $500 \mu \mathrm{l} \mathrm{RNAlater}$ (Invitrogen) and the excess swab handle was broken by bending. Samples were preserved in RNAlater solution to preserve DNA/RNA and viable spores which could then be cultivated for positive samples (Puechmaille et al. 2011c, Dool et al. 2018). To avoid cross-contamination, sterile rubber gloves were worn at each sampling site, and swab tips or sampling areas were not touched with gloves or hands. At the time of sampling, no living bats were seen in the caves.

Samples were preserved at $-20^{\circ} \mathrm{C}$ until DNA extraction. To avoid cross-contamination, all steps with open tubes were carried out under a laminar flow hood exposed to UV 
light before use and only one tube was open at a time. Prior to DNA extraction, the RNAlater solution was removed as recommended by the Ambion User Guide. The material was centrifuged for $10 \mathrm{~min}$ at 7,500 rpm before the RNAlater was removed by pipette without disturbing the formed pellet. The samples were then soaked for $5 \mathrm{~min}$ at room temperature in $500 \mu \mathrm{l}$ PBS. The material was centrifuged for $10 \mathrm{~min}$ at 7,500 rpm before the PBS was removed by pipette without disturbing the pellet. The swab was turned upside down with sterile tweezers and placed back into the same tube. The sample was then centrifuged for $5 \mathrm{~min}$ at $13,000 \mathrm{rpm}$. DNA extraction was then performed by dispensing $100 \mu \mathrm{l}$ of PrepMan ${ }^{\circledR}$ Ultra Sample Preparation Reagent (Cat No. 4318930 from Life Technologies) into a $1.5 \mathrm{ml}$ tube to which $30 \mu \mathrm{l}$ of the sample was added (taken after pipetting the sample solution up and down until homogeneous; the remaining being saved for cultivation). The samples were then vigorously vortexed for $30 \mathrm{~s}$ and then incubated in a heat block set to $100{ }^{\circ} \mathrm{C}$ for $10 \mathrm{~min}$ while shaking at $1,000 \mathrm{rpm}$. Samples were removed from the heat block and allowed to cool to room temperature for $2 \mathrm{~min}$. The samples were then centrifuged at 13,000 rpm for $2 \mathrm{~min}$. A volume of $50 \mu$ l of the supernatant was transferred to a new tube and subsequently used as the template in the qPCR.

Real-time PCR was performed targeting the intergenic spacer (IGS) region of $P$. destructans. The Real-time IGS PCR assay was conducted using an ABI 7500 Fast Real-Time PCR system (Applied Biosystems) and the commercial master mix (QuantiFast ${ }^{\mathrm{TM}}$ Probe PCR + ROX Vial Kit, QIAGEN Inc.) as described in Muller et al. (2013). The $25 \mu$ l PCR reaction contained $1 \times$ QuantiFast Probe PCR Master Mix, 1× ROX dye solution, $0.4 \mu \mathrm{M}$ of each primer (nuIGS-0169-5'-Gd and nu-IGS-0235-3'-Gd), $0.2 \mu \mathrm{M}$ dual-labelled BHQ-1 probe (SigmaAldrich), $32 \mathrm{ng}$ of bovine serum albumin to reduce potential PCR inhibition, and $5 \mu \mathrm{l}$ template DNA. Samples that did not cross the threshold baseline before cycle 40 were considered negative. The threshold baseline was set to $10 \%$ of the maximum fluorescence as determined by positive control samples. Negative and positive controls were also run with the qPCR. Positive controls were composed of DNA extracted from previously confirmed $P$. destructans (Gd00040-a) and DNA extracted from wall swabs collected at a hibernaculum near Greifswald, Germany. One wall swab was used as a positive control as it was collected from a wall that was in contact with visibly infected bats and from which $P$. destructans was previously isolated (Dool et al. 2018). Hence this swab was used as a positive control for the full lab procedure, including DNA extraction and $\mathrm{qPCR}$.

\section{RESULTS}

Pseudogymnoascus destructans DNA was not detected in any of the 85 Hawaiian substrate swabs via the IGS-qPCR, hence no culture was carried out. All positive and negative controls used in the qPCR were positive and negative respectively. The caves that we sampled ranged from 240 to $3,045 \mathrm{~m}$ above sea level and daytime temperatures during sampling ranged from 7.0 to $21.6^{\circ} \mathrm{C}$ (Table 1). At night, winter temperatures close to the entrances inside caves may fall below freezing and snow may be present on the ground outside some of the caves sampled.

\section{DISCUSSION}

Pseudogymnoascus destructans was not detected in any of the wall swabs we collected from 10 caves in Hawai'i. In previous research, Lorch et al. (2013) estimated a $98 \%$ probability of detecting $P$. destructans in a WNS-positive site in the Eastern US using just five qPCR samples, including during the active season and in the absence of bats, which supports the reliability of our methods. However, the absence of evidence of $P$. destructans in the caves we investigated is not an evidence for its absence on the island: the fungus may be present in lower quantities in comparison to sites where bats are more susceptible to WNS or may be present in other caves not sampled during the present study. Despite these limitations, this is the first attempt to implement any monitoring to detect the potential arrival of $P$. destructans in Hawai' $i$, 
and can be expanded to cover a larger number of caves and a larger number of samples per site. Considering that the fungus can spread rapidly once it arrives at a certain site (Langwig et al. 2015), its early detection is crucial for the implementation of timely counter-measures.

Pseudogymnoascus destructans recently has crossed large geographic barriers of both sea and land, first across the Atlantic Ocean from Europe to North America (Leopardi et al. 2015) and then across large areas of the Great Plains of North America to Washington State (Lorch et al. 2016). Spread of the fungus is suspected to occur both by bats and human activities, however, the large distance invasions into previously uninfected areas have most likely been due to humans (Leopardi et al. 2015). Since the Hoary bat colonised the Hawaiian islands, no long-distance dispersals to or from North America have been reported. If such dispersals were to take place, they are only likely in the direction from North America to Hawai' $\mathrm{i}$ (Bonaccorso \& McGuire 2013). It is more probable that bat arrivals to Hawai'i will occur due to human activities (e.g. unintentional translocations by air or sea, Constantine 2003). Human vectors remain the most likely of all. Given the great number of tourists that visit the Hawaiian Islands every year according to the Hawai' $i$ Tourism Authority (8,679,564 for 2015: Nahoopii et al. 2015), including many caving enthusiasts, the inadvertent transport of $P$. destructans spores from sites in North America and/or Eurasia on contaminated clothing, shoes, or equipment is a possible means for this fungus to become established in caves in the Hawaiian Archipelago where high elevation microclimates are suitable for its persistence once present. To avoid inadvertent transport of $P$. destructans, the U.S. Fish and Wildlife Service provide a National White-nose Syndrome decontamination protocol (available at www.whitenosesyn drome.org/topics/decontamination).

As a precautionary measure against $P$. destructans introduction, the National Park Service in Hawai'i Volcanoes and Haleakalā National Parks requires permits to enter most caves. These permits state the following: "Under no circumstances should clothing, footwear, or gear that was used in a White-Nose Syndrome- affected state or region be used". However, many lava tube caves on state and private lands, including those of the Mauna Loa Forest Reserve, are easily visible to the public but lack signage or physical barriers indicating the legal requirement for an entry permit issued by the Hawaiian Department of Land and Natural Resources. Thus, many caves in Hawai'i may be susceptible to translocations of microbes from any part of the world including WNS areas.

\section{CONCLUSIONS}

Given the large number of caves with suitable microclimates to support $P$. destructans and the popularity of cave tourism and recreation, land managers and regulatory agencies in Hawai'i may want to remain vigilant for the establishment of this fungus in cold caves and promote or require preventative measures for those entering caves (e.g. decontamination of equipment: Shelley et al. 2013). Periodic screening for $P$. destructans in Hawai'i's cold caves to detect the potential arrival of this devastating pathogen could help to avoid further spread.

\section{ACKNOWLEDGMENTS}

We thank P. Bosted, R. Mosely, and S. Smith for guiding us through caves under their stewardship following permission granted by Pohakuloa Training Area, the Cave Conservancy of Hawai' $i$, and the Hawai' $i$ Department of Land and Natural Resources. We thank L. Perry, Hawai'i Division of Forestry and Wildlife, for facilitating the issuance of access permits for research in caves within the Mauna Loa Forest Reserve. Constructive reviews were provided by J. Jacobi and L. Perry. Any use of trade, firm, or product names is for descriptive purposes only and does not imply endorsement by the U.S. Government.

\section{Literature Cited}

Badino, G. 2004. Cave temperatures and global climatic change. Int. J. Speleol. 33:103-113. doi: 10.5038/1827-806X.33.1.10. 
Barnes, I., A. Fourie, M. J. Wingfield, T. C. Harrington, D. L. McNew, L. S. Sugiyama, B. C. Luiz, W. P. Heller, and L. M. Keith. 2018. New Ceratocystis species associated with rapid death of Metrosideros polymorpha in Hawai'i. Persoonia 40:154181. doi: 10.3767/persoonia.2018.40.07.

Bertelsmeier, C., S. Ollier, A. Liebhold, and L. Keller. 2017. Recent human history governs global ant invasion dynamics. Nat. Ecol. Evol. 1:184. doi: 10.1038/s41559017-0184.

Bonaccorso, F. J., and L. P. McGuire. 2013. Modeling the colonization of Hawaii by hoary bats (Lasiurus cinereus). Pages 187206 in R. Adams and S. C. Pedersen, eds. Bat evolution, ecology, and conservation. Springer Science Press.

Bonaccorso, F. J., C. M. Todd, A. C. Miles, and P. M. Gorresen. 2015. Foraging range movements of the endangered Hawaiian hoary bat, Lasiurus cinereus semotus (Chiroptera: Vespertilionidae). J. Mammal. 96:64-71. doi: 10.1093/jmammal/gyu003.

Bonaccorso, F. J., K. Montoya-Aiona, C. A. Pinzari, and C. M. Todd. 2016. Winter distribution and use of high elevation caves as foraging sites by the endangered Hawaiian hoary bat, Lasiurus cinereus semotus. University of Hawai'i at Hilo Technical Report 68:1-24.

De Castro, F., and B. Bolker. 2005. Mechanisms of disease-induced extinction. Ecol. Lett. 8:117-126. doi: 10.1111/j.14610248.2004.00693.x.

Constantine, D. G. 2003. Geographic translocation of bats: Known and potential problems. Emerg. Infect. Dis. 9:17-21.

Cryan, P. M., C. Meteyer, J. G. Boyles, and D. S. Blehert. 2010. Wing pathology of white-nose syndrome in bats suggests life-threatening disruption of physiology. BMC Biol. 8:135. doi: 10.1186/1741-70078-135.

Cunningham, A. A., P. Daszak, and J. P. Rodríguez. 2003. Pathogen pollution: Defining a parasitological threat to biodiversity conservation. J. Parasitol. 89:S78-S83. doi: 10.1111/j.1523-1739.2010.01483.x.

Daszak, P., A. A. Cunningham, and A. D. Hyatt. 2000. Emerging infectious diseases of wildlife threats to biodiversity and human health. Science 287:443-449. doi: 10.1126/science.287.5452.443.

Dool, S. E., A. Altewischer, N. M. Fischer, K. P. Drees, J. T. Foster, M. Fritze, and S. J. Puechmaille. 2018. Mating type determination within a microsatellite multiplex for the fungal pathogen Pseudogymnoascus destructans, the causative agent of whitenose disease in bats. Conserv. Genet. Resour. doi: 10.1007/s12686-018-1064-6.

Drees, K. P., J. M. Lorch, S. J. Puechmaille, K. L. Parise, G. Wibbelt, J. R. Hoyt, K. Sun, A. Jargalsaikhan, M. Dalannast, J. M. Palmer, D. L. Lindner, A. M. Kilpatrick, T. Pearson, P. S. Keim, D. S. Blehert, and J. T. Foster. 2017. Phylogenetics of a fungal invasion: Origins and widespread dispersal of white-nose syndrome. mBio 8:e0194101917. doi: 10.1128/mBio.01941-17.

Dyer, E. E., P. Cassey, D. W. Redding, B. Collen, V. Franks, K. J. Gaston, K. E. Jones, S. Kark, C. D. L. Orme, and T. M. Blackburn. 2017. The global distribution and drivers of alien bird species richness. PLoS Biol. 15:1-25. doi: 10.1371/journal. pbio.2000942.

Fisher, M. C., D. A. Henk, C. J. Briggs, J. S. Brownstein, L. C. Madoff, S. L. McCraw, and S. J. Gurr. 2012. Emerging fungal threats to animal, plant and ecosystem health. Nature 484:186-194. doi: 10.1038/ nature10947.

Fisher, M. C., N. A. R. Gow, and S. J. Gurr. 2016. Tackling emerging fungal threats to animal health, food security and ecosystem resilience. Philos. Trans. R. Soc. B: Biol. Sci. 371:20160332. doi: 10.1098/rstb.2016 .0332 .

Frick, W. F., S. J. Puechmaille, J. R. Hoyt, B. A. Nickel, K. E. Langwig, J. T. Foster, K. E. Barlow, T. Bartonička, D. Feller, A.-J. Haarsma, C. Herzog, I. Horáček, J. Kooij, B. Mulkens, B. Petrov, R. Reynolds, L. Rodrigues, C. W. Stihler, G. G. Turner, and A. M. Kilpatrick. 2015. Disease alters macroecological patterns of North American bats. Glob. Ecol. Biogeogr. 24:741749. doi: 10.1111/geb.12290.

Frick, W. F., S. J. Puechmaille, and C. K. R. Willis. 2016. White-nose syndrome in 
bats. Pages 245-262 in C. Voigt and T. Kingston, eds. Bats in the Anthropocene: Conservation of bats in a changing world. USA: Springer International Publ. doi: 10.1007/978-3-319-25220-9_9.

Fritze, M., and S. J. Puechmaille. 2018. Identifying unusual mortality events in bats: A baseline for bat hibernation monitoring and white-nose research. Mammal Rev. 48:224-228. doi: 10.1111/mam.12122.

Kovacova, V., J. Zukal, H. Bandouchova, A. D. Botvinkin, M. Harazim, N. Martínková, O. L. Orlov, V. Piacek, A. P. Shumkina, M. P. Tiunov, and J. Pikula.2018. Whitenose syndrome detected in bats over an extensive area of Russia. BMC Vet. Res. 14:192. doi: 10.1186/s12917-018-1521-1.

Langwig, K., J. R. Hoyt, K. L. Parise, J. A. Kath, D. Kirk, W. F. Frick, J. T. Foster, and A. M. Kilpatrick. 2015. Invasion dynamics of white-nose syndrome fungus, midwestern United States, 2012-2014. Emerg. Infect. Dis. 21:1023.

Leopardi, S., D. Blake, and S. J. Puechmaille. 2015. White-nose syndrome fungus introduced from Europe to North America. Curr. Biol. 25:R217-R219. doi: 10.1016/j. cub.2015.01.047.

Lombaert, E., T. Guillemaud, J.-M. Cornuet, T. Malausa, B. Facon, and A. Estoup. 2010. Bridgehead effect in the worldwide invasion of the biocontrol harlequin ladybird. PLoS ONE 5(3):e9743. doi: 10.1371/ journal.pone.0009743.

Lorch, J. M., L. K. Muller, R. E. Russell, M. O'Connor, D. L. Lindner, and D. S. Blehert. 2013. Distribution and environmental persistence of the causative agent of white-nose syndrome, Geomyces destructans, in bat hibernacula of the Eastern United States. Appl. Env. Microbiol. 79:1293-1301.

Lorch, J. M., J. M. Palmer, D. L. Lindner, A. E. Ballmann, K. G. George, K. Griffin, S. Knowles, J. R. Huckabee, K. H. Haman, C. D. Anderson, P. A. Becker, J. B. Buchanan, J. T. Foster, and D. S. Blehert. 2016. First detection of bat White-nose syndrome in Western North America. mSphere 1:e00148-16.doi: 10.1128/mSphere. 00148-16.
Muller, L. K., J. M. Lorch, D. L. Lindner, M. O'Connor, A. Gargas, and D. S. Blehert. 2013. Bat white-nose syndrome: A realtime TaqMan polymerase chain reaction test targeting the intergenic spacer region of Geomyces destructans. Mycologia 105:253-259. doi: 10.3852/12-242.

Nahoopii, D., J. Chun, M. C. Chun, and L. Liu. 2015. Annual Visitor Research Report. Hawai'i Tourism Authority. Accessed August 2017. http://www.hawaii tourismauthority.org/default/assets/File/ reports/visitor-statistics/2015.

Petit, E. J., and S. J. Puechmaille. 2015. Will reduced host connectivity curb the spread of a devastating epidemic? Mol. Ecol. 24:5491-5494. doi: 10.1111/mec.13406.

Puechmaille, S. J., P. Verdeyroux, H. Fuller, M. A. Gouilh, M. Bekaert, and E. C. Teeling. 2010. White-nose syndrome fungus (Geomyces destructans) in bat, France. Emerg. Infect. Dis. 16:290-293. doi: 10.3201/eid1602.091391.

Puechmaille, S. J., W. Frick, T. H. Kunz, P. A. Racey, C. C. Voigt, G. Wibbelt, and E. C. Teeling. 2011a. White-nose syndrome: Is this emerging disease a threat to European bats? Trends Ecol. Evol. 26:570-576. doi: 10.1016/j.tree.2011.06.013.

Puechmaille, S. J., G. Wibbelt, V. Korn, H. Fuller, F. Forget, K. Mühldorfer, A. Kurth, W. Bogdanowicz, C. Borel, T. Bosch, T. Cherezy, M. Drebet, T. Görföl, A.-J. Haarsma, F. Herhaus, G. Hallart, M. Hammer, C. Jungmann, Y. Le Bris, L. Lutsar, M. Masing, B. Mulkens, K. Passior, M. Starrach, A. Wojtaszewski, U. Zöphel, and E. C. Teeling. 2011b. Pan-European distribution of white-nose syndrome fungus (Geomyces destructans) not associated with mass mortality. PLoS ONE 6(4):e19167. doi: 10.1371/journal.pone.0019167.

Puechmaille, S. J., H. Fuller, H., and E. C. Teeling. 2011c. Effect of sample preservation methods on the viability of Geomyces destructans, the fungus associated with white-nose syndrome in bats. Acta Chiropt. 13:217-221. doi: 10.3161/150811011X578778.

Raudabaugh, D. B., and A. N. Miller. 2013. Nutritional capability and substrate 
suitability for Pseudogymnoascus destructans, the causal agent of bat White-nose syndrome. PLoS ONE 8:1-9. doi: 10.1371/journal. pone. 0078300 .

Reeder, D. M., and G. R. Turner. 2008. Working together to combat White-nose syndrome: A report of a meeting on 9-11 June 2008, in Albany, New York. Bat Res. News 49:75-78.

Reynolds, H. T., T. Ingersoll, and H. A. Barton. 2015. Modeling the environmental growth of Pseudogymnoascus destructans and its impact on the White-nose syndrome epidemic. J. Wildl. Dis. 51:318-331. doi: 10.7589/2014-06-157.

Roques, A., M. A. Auger-Rozenberg, T. M. Blackburn, J. Garnas, P. Pyšek, W. Rabitsch, D. M. Richardson, M. J. Wingfield, A. M. Liebhold, and R. P. Duncan. 2016. Temporal and interspecific variation in rates of spread for insect species invading Europe during the last 200 years. Biol. Invasions 18:907-920. doi: 10.1007/ s10530-016-1080-y.

Shelley, V., S. Kaiser, E. Shelley, T. Williams, M. Kramer, K. Haman, K. Keel, and H. A. Barton. 2013. Evaluation of strategies for the decontamination of equipment for Geomyces destructans, the causative agent of white-nose syndrome (WNS). J. Cave Karst Stud. 75:1-10. doi: 10.4311/ 2011 LSC0249.

Smith, K. M., C. Zambrana-Torrelio, A. White, M. Asmussen, C. Machalaba, S. Kennedy, K. Lopez, T. M. Wolf, P. Daszak, D. A. Travis, and W. B. Karesh. 2017. Summarizing US wildlife trade with an eye toward assessing the risk of infectious disease introduction. Ecohealth 14:29-39. doi: 10.1007/s10393-0171211-7.
Stone, M. 2017. Tree killing fungus continues to spread on Hawaii's biggest island. Bioscience 67(8):776. doi: 10.1093/biosci/ bix076.

Turner, G. R., and D. M. Reeder. 2009. Update of White-nose syndrome in bats, September 2009. Bat Res. News 50:47-53.

U.S. Fish and Wildlife Service. 2017. White Nose Syndrome, the devastating disease of hibernating bats in North America. Accessed September 2017. https://www. whitenosesyndrome.org/sites/default/files/ resource/white-nose_fact_sheet_4-2017_0. pdf.

—. 2018. White-nose syndrome occurance map by year. Accessed August 2018. https://www.whitenosesyndrome.org/sta tic-page/where-is-wns-now.

Veilleux, J. P. 2008. Current status of Whitenose syndrome in the Northeastern United States. Bat Res. News 49:15-17.

Verant, M. L., J. G. Boyles, W. Waldrep, G. Wibbelt, and D. S. Blehert. 2012. Temperature-dependent growth of Geomyces destructans, the fungus that causes bat White-nose syndrome. PLoS ONE 7(9): e46280. doi: 10.1371/journal.pone.0046280.

Vitousek, P. M., H. A. Mooney, J. Lubchenco, and J. M. Melillo. 1997. Human domination of Earth's ecosystems. Science 277:494-499. doi: 10.1126/science.277.5325.494.

Zukal, J., H. Bandouchova, J. Brichta, A. Cmokova, K. S. Jaron, M. Kolarik, V. Kovacova, A. Kubátová, A. Nováková, O. Orlov, J. Pikula, P. Presetnik, J. Šuba, A. Zahradníková Jr., and N. Martínková. 2016. White-nose syndrome without borders: Pseudogymnoascus destructans infection tolerated in Europe and Palearctic Asia but not in North America. Sci. Rep. 6:19829. doi: $10.1038 /$ srep19. 
Downloaded From: https://bioone.org/journals/Pacific-Science on 09 Feb 2021

Terms of Use: https://bioone.org/terms-of-use Access provided by Centre de Cooperation Internationale en Recherche Agronomique pour le Developpement 